\title{
DIMENSIES VAN LEIERSKAPSBEOEFENING DEUR VERPLEEGDIENSBESTUURDERS
}

\author{
A Nel, M Muller en M Poggenpoel
}

\section{UITTREKSEL}

Leierskapsontwikkeling vorm 'n belangrike komponent van die verpleegdiensbestuurder se persoonlike en professionele ontwikkeling. Bekwame leierskap word vereis om ' $n$ verpleegdiens binne die konteks van dinamiese politieke en maatskaplike veranderinge in die regte rigting te lei. Verskeie interne en eksterne omgewingsveranderlikes is bepalend vir voortreflike leierskapsbeoefening. Die doel met hierdie studie is om die kenmerke of dimensies van voortreflike leierskapsbeoefening deur die verpleegdiensbestuurder te verken en te beskryf. ' $n$ Verkennende en beskrywende navorsingsontwerp is gevolg en die data-insameling is by wyse van fokusgroeponderhoude gedoen. Die resultate toon geen betekenisvolle verskil tussen die kennis wat reeds deur die literatuur en navorsing bevestig is nie, maar is gebruik om as basis te dien vir leierskapsontwikkeling van verpleegdiensbestuurders. 'n Leierskapsontwikkelingsprogram vir verpleegdiensbestuurders, gebaseer op die resultate van hierdie studie, word ondermeer aanbeveel.

\begin{abstract}
Leadership development is an important component of the nursing service manager's personal and professional development. Competent leadership is required to lead the nursing service in the right direction within the context of dynamic political and social changes. Various internal and extemal environmental variables have a significant influence on leadership behaviour and practice. The purpose with this study is to explore and describe the characteristics or dimensions of leadership excellence by the nursing service manager. An exporatory and descriptive research design was followed and data collection was done by means of focus group interviews. The results do not show a significant difference between the knowledge already generated by research, or described in the literature, but is utilised as the basis of leadership development of. nursing service managers. A leadership development programme for nursing service managers, based on the results of this study, is recommended.
\end{abstract}

\section{INLEIDING}

Dinamiese veranderinge in die gesondheidsdienste vereis voortreflike leierskapsbeoffening deur die verpleegdiensbestuurder. Dit het dringend noodsaaklik geword dat daar aandag aan die leierskapsvermö̈ns (kennis, vaardighede en houdings) van die verpleegdiensbestuurder geskenk word. Verskeie interne en eksterne omgewingsveranderlikes is bepalend vir voortreflike leierskapsbeoefening. So byvoorbeeld oefen verhoogde tegnologiese kennis, spesialisering, die veranderende gesondheidsprofiel van die Suid-Afrikaanse bevolking. herposisionering van die vrou in die arbeidsmark, veranderinge in die politieke en maatskaplike klimaat, veranderde bestuurseise in die gesondheidsdienste. ensovoorts, ' $n$ invloed uit op die verpleegdiensbestuurder se leidinggewende verantwoordelikheid in die verpleegdiens.

Volgens Kotzè (1991:4) lê die sleutel vir voortgesette versiendheid in verplegingsberoepsgeledere op die gebied van leierskapsontwikkeling en die lewering van genoegsame bevoegde leiers op elke vlak van die verpleegkundige se funksionering in die gesondheidsdienste. Die bestuursvlak vereis juis bekwame leierskap, veral nou in die tyd waar herposisionering van verpleegdienste aan die orde van die dag is. Om veranderinge in die regte rigting te lei, word nie net bestuursvaardighede nie, maar ook leierskapsvaardighede vereis.
Leierskapsontwikkeling vorm dus 'n belangrike komponent van die verpleegdiensbestuurder se persoonlike en professionele ontwikkeling. ' $n$ Model vir leierskapsontwikkeling word benodig om as raamwerk vir 'n leierskapsontwikkelingsprogram te benut. Alvorens ' $n$ model vir leierskapsontwikkeling ontwikkel kan word; behoort die eienskappe van voortreflike leierskapsbeoefening, binne die konteks van verpleegdiensbestuur, beskikbaar te wees. Hierdie studie is gebaseer op die teoretiese raamwerk van Verplegingsteorie vir Mensheelheid ("Nursing for the Whole Person Theory") soos ontwikkel is deur die "Oral Roberts University" (1990), met 'n heelpersoonbenadering wat gevolg word. Geen riglyne vir leierskapsontwikkeling is ingevolge hierdie teoretiese raamwerk eksplisiet beskikbaar nie. Voorts is die kenmerke van voortreflike leierskapsbeoefening deur die verpleegdiensbestuurder ook nog nie vanuit hierdie teoretiese benadering verken en beskryf nie. Die volgende navorsingsvrae is tersaaklik, naamlik hoe word leierskapsbeoefening deur die verpleegdiensbestuurders beskou en wat is die kenmerke van voortreflike leierskapsbeoefening deur die verpleegdiensbestuurder binne Suid-Afrikaanse konteks?

Die doel met hierdie artikel is om die verpleegdiensbestuurder se beskouing omtrent leierskapsbeoefening - en derhalwe die dimensies van voortreflike leierskapsbeoefening - te verken en te beskryf. Hierdie dimensies van voortreflike leierskapsbeoefening sal as basis dien vir die konseptualisering $v a n$ ' $n$ model vir leierskapsontwikkeling van verpleegdiensbestuurders, wat in ' $n$ opvolgartikel weergegee sal word.

\section{TERMINOLOGIE}

\section{Verpleegdiensbestuurder}

'n Verpleegdiensbestuurder is in geregistreerde verpleegkundige wat 'n verpleegdiens bestuur en derhalwe verantwoordelik is vir die bestuursuitsette van die verpleegdiens.

\section{Leierskapsbeoefening}

Leierskapsbeoefening is die wyse waarop die verpleegdiensbestuurder leiding aan haar/sy volgelinge in die verpleegdiens gee, binne die 
raamwerk van die gesondheidsdiens se missie en doelstellings. ' $n$ Finale konseptuele definisie vir leierskapsbeoefening word na aanleiding van die resultate afgelei en gedefinieer.

\section{Dimensies}

Die dimensies is die kenmerke van voortreflike leierskapsbeoefening, wat as sentrale konsepte vir die ontwikkeling van 'n model vir leierskapsontwikkeling van verpleegdiensbestuurders dien en as basis gebruik word vir die ontwikkeling van 'n program vir leierskapsontwikkeling van verpleegdiensbestuurders.

\section{NAVORSINGSONTWERP}

' $n$ Verkennende, beskrywende navorsingsontwerp is gevolg om die dimensies van voortreflike leierskapsbeoefening, binne die konteks van verpleegdiensbestuur, te verken en te beskryf. ' $n$ Induktiewe en kwalitatiewe navorsingsoriëntasie is gevolg deur 'n fokusgroeponderhoud met verpleeg-diensbestuurders en verpleegleiers te voer, gevolg deur ' $n$ literatuurkontrole en Verplegingsteorie vir Mensheelheid as teoretiese raamwerk.

Die fokusgroeponderhoud is as datainsamelingstegniek gebruik, soos beskryf deur Kingry, Tiedje en Friedman (1990:124). Dit is ' $n$ deeglik beplande bespreking deur ' $n$ homogene groep persone, om persepsies van 'n spesifieke gedefinieerde aspek van belang in 'n nie-bedreigende omgewing te verkry.

Die ideale grootte vir ' $n$ fokusgroep is tien deelnemers om ' $n$ regverdige geleentheid vir deelname te gee. Die deelnemers se persepsies en beskouinge omtrent leierskapsbeoefening deur die verpleegdiensbestuurder is verken, asook die wyse waarop leierskapsontwikkeling kan plaasvind. ' $n$ Psigiatriese verpleegspesialis, met bevestigde onderhoudvoeringsvaardighede, het as tussenganger opgetree om die deelnemers aan die fokusgroep saam te roep en om die fokusgroeponderhoude te voer. Die navorser was teenwoordig tydens die fokusgroeponderhoude en het veldnotas afgeneem ten einde die data beter te verstaan, te ondersteun en as hulp in die sintetisering van die data (Field \& Morse, 1985:80; Polit \& Hungler, 1987:271). Die fokus groeponderhoude is op audioband vasgelê en vervolgens verbatim getranskribeer ter voorbereiding van die data-ontleding.

'n Nasionaal-verteenwoordigende groep verpleegleiers het die steekproef vir die onderhoudvoering gevorm. Die groep verteenwoordig nasionaalverkose verpleegleiers, asook verpleegdiensbestuurders in topbestuursposte (soos diè van Direkteur of Adjunk-direkteur, en Hoofverpleegdiensbestuurders). Die verpleegkundige akademie en die privaatsektor was ook verteenwoordig. Die nasionaalverkose groep is verpleegkundiges wat deur die verpleegprofessie op " $n$ demokratiese wyse verkies is om op ' $n$ nasionale bestuurliggaam in die verpleegberoep te dien -hul leierskap is derhalwe op hierdie wyse erken. Aangesien hierdie groep nasionale verpleegleiers verteenwoordig is hulle genader om aan die fokusgroep op ' $n$ vrywillige basis deelgeneem.

Die groep is in twee verdeel om eerstens aan die groepgrootte-vereistes vir fokusgroeponderhoudvoering (maksimum van twaalf lede per groep) te voldoen en om tweedens vir taalkeuse (Afrikaans of Engels) voorsiening te maak. Daar is gepoog om verteenwoordiging vanuit alle rassegroepe te verseker. Etiese beginsels, soos aanbeveel deur Parse, Coyne en Smith (1985:93) is nagevolg, soos die verkryging van vrywillige, ingeligte toestemming, versekering van vertroulikheid en anonimiteit, asook die hantering en verifiëring van die resultate en ander moontlike nagevolge van onderhoudvoering.

'n Voorondersoek is met vier verpleegdiensbestuurders gedoen, om die voorbereiding vir onderhoudvoering te toets en om te bepaal of die vraagstelling aan die vereistes van duidelikheid voldoen het.

Die data-ontleding is deur die navorser en ' $n$ onafhanklike kodeerder gedoen, aan die hand van Verplegingsteorie vir Mensheelheid se eenheid van beraming, naamlik interne omgewing (liggaam, siel en gees), eksterne omgewing (fisiek, sosiaal en geestelik), en die kenmerkende wyses van interaksie nussen die interne en eksterne omgewings. Die onderliggende aanname is dus dat die mens uit liggaam, siel en gees bestaan wat op ' $n$ geintegreerde wyse as 'n eenheid funksioneer en met sy eksterne omgewing in voortdurende interaksie is, 0ok in die beoffening van leierskap.

Kerlinger (1986:477/481) se riglyne vir inhoudsontleding is gevolg, naamlik die lees en herlees van die transkripsies, identifisering van hooftemas en subkategorieè. Kwantifisering van data is nie gedoen nie, aangesien slegs twee onderhoude gevoer is. Vervolgens is 'n literatuurkontrole uitgevoer om coreenkomste en verskille te identifiseer en ook om die vertrouenswaardigheid van die studie te verhoog.

Verskeie maatreëls om die vertrouenswaardigheid van die studie te verhoog, is nagevolg (Mouton \& Marais, 1990:72/81; Field \& Morse, 1985:139; Woods \& Catanzaro, 1988:136/137):

- 'n verteenwoordigende seleksie van deelnemers om verpleegdiensbestuurders en verpleegleiers op nasionale vlak te verteenwoordig;

- homogeniteit van die deelnemers deurdat almal verpleegkundiges is wat aan die seleksie-kriteria voldoen het;

- 'n duidelike uiteensetting van die doel met die onderhoud en die rolle van die onderhoudvoerder en navorser;
- die daarstelling van ' $n$ nie-bedreigende en steuringsvrye eksterne omgewing tydens onderhoudvoering;

- die demonstrering van voortreflike onderhoudvoerings-vermoëns deur die onderhoudvoerder;

- die afneem van veldnotas deur die navorser tydens die onderhoudvoering;

- verbatim transkribering van die onderhoude;

- onafhanklike kodering van data deur die navorser en twee onafhanklike navorsers, met konsensusbesluitneming betreffende die finale resultate;

- verifiëring van die onderhoudvoeringsresultate met ' $n$ groep bestaande uit sewe van die persone wat aan die eerste fokusgroeponderhoud deelgeneem het;

- 'n literatuurkontrole.

Direkte aanhalings vanuit die getranskribeerde onderhoude word gebruik om die presiese woorde van die deelnemers te reflekteer. Sodoende word onbetroubare interpretasies voorkom.

\section{RESULTATE}

\section{Steekproefrealisering}

Twee fokusgroeponderhoude is gevoer met ' $n$ somtotaal van veertien verpleegdiensbestuurders/leiers wat deelgeneem het. Tien deelnemers het die openbare sektor verteenwoordig en beklee topbestuursposte en drie deelnemers is vanuit die akademie -universiteit en verplegingskollege. Die privaatsektor is ook verteenwoordig. Geografies is al nege ontwikkelingstreke van die land verteenwoordig. Alle rassegroepe is in die fokusgroepe verteenwoordig en daarom is een van die onderhoude in Engels gevoer.

Die volgende dimensies van voortreflike leierskapsbeoefening is geïdentifiseer, naamlik rolmodel, deelnemende leierskap, interpersoonlike vaardighede, die verpleegleier se waardes, veranderingsbestuur asook selfbestuur. Binne die eenheid van beraming ingevolge die Verplegingsteorie vir Mensheelheid, is al hierdie dimensies kenmerkende wyses van interaksie tussen die interne en eksterne omgewings van die verpleegleier, behalwe waardes was as in interne geestelike dimensie geklassifiseer word. Die algemene beskrywing van resultate omtrent hierdie leierskapsdimensies word weergegee, asook die deelnemers se beskouings oor leierskapsontwikkeling. Laastens word die leierskapsdimensies konseptueel binne die konteks van leierskapsbeoefening in ' $n$ verpleegdiens beskryf, om as basis te dien vir die ontwikkeling van ' $n$ model vir leierskapsontwikkeling van verpleegdiensbestuurders. 
Dimensies van voortreflike leierskapsbeoefening

a) Die verpleegleier as rolmodel Rolmodelskap deur die verpleegdiensbestuurder as leier, is baie beklemtoon en is as een van die mees belangrike dimensies van leierskaps- beofening voorgehou, asook die mees kritiese leierskapsontwikkelingstrategie. ' $n$ Rolmodel beskik oor al die leierskaps- kwaliteite, karaktereienskappe en bestuursvaardighede wat die verpleegdiensbestuurder as leier benodig. Persoonlike eienskappe is beklemtoon (liggaamlik, psigies en geestelik) wat deur die verpleegdiensbestuurder as leier geopenbaar moet word. Die verpleegdiensbestuurder as rolmodel behoort te weet wat haar rol in verpleging en in die gemeenskap behels: "As I see it you must know exactly what your role is and where you want to go and what your aims and objectives are. The leader acts as a role model." Die grootste klem is hier gelê op die fasilitering van gehalteverpleging as doelwit.

Verder behoort die verpleegdiensbestuurder deur haar/sy rolmodelskap ' $n$ verbintenis tot leierskapsontwikkeling van haar/sy volgelinge te openbaar. Een deelnemer het dit sterk gestel: "Wys vir my die leiers wat deur 'n persoon na vore gebring is en ek weet hoe 'n goeie leier sy was." Persoonlike (interne omgewing) eienskappe wat deur die groepe gestel was, was onder andere selfvertroue, integriteit, sterk oortuigings en waardes, goeie kommunikasie en interpersoonlike vaardighede: "Ek kan dink aan briljante verpleegleiers, maar hulle skiet te kort omdat hulle partykeer in die persoonlike samestelling tekortkominge het."

Die meeste literatuur oor leierskap bevestig die belangrikheid van rolmodellering as ' $n$ kenmerk van voortreflike leierskapsbeoefening (Coetzee, 1990:16; Rush, 1989:235; Mulder, 1990:82/85).

b) Deelnemende leierskap in verpleegbestuur

Deelnemende leierskap- of bestuursvaardighede is deur die deelnemers beklemtoon. Hier is konsepte soos spanbou, motivering en begeleiding aangespreek. Die verpleegdiensbestuurder behoort die groep te ken (liggaamlik/fisiek, psigies/sosiaal en geestelik) ten opsigte van hul vermoëns en verwagtinge. Die verpleegdiensbestuurder behoort selfvertroue by die volgelinge te fasiliteer: "You cannot have the confidence of participative management and participatory effor if your group is not confident to work this ..." Leidinggewing is belangrik: " ... maar dan moet jy in die eerste plek weet waarheen jy gaan en jy moet vir die mense laat weet waar gaan jy heen en jy moet vir hulle die geleentheid gee om self te ontwikkel sodat hulle die pad saam met jou kan loop." Dit vereis die aanwending van deelnemende bestuurs/leierskapsvaardighede. Spanbou is die noodwendige gevolg van deelnemende leierskap: "Leierskap op bestuursvlak is nie altyd die resultaat van die leidinggewing van net een persoon nie - dis vandag in oorweging die resultaat van dit wat uit ' $n$ groep - ' $n$ saamgesnoerde groep - wat op 'n spesifieke doelstelling ingestel is en 'n spesifieke saak dien na vore kom. Oorwegend vandag is dit " $n$ groep persone wat gesamentlik deelneem aan hierdie besluitnemingsproses." Groepsfunksionering en deelnemende leierskap / bestuur / besluitneming vorm die kern van sukses in 'n verpleegdiens. Dit fasiliteer ook wedersydse vertroue en ondersteuning tussen die leier en volgelinge. Hierdie beginsel van groepsbesluitneming behoort ook na die gemeenskap deurgevoer te word. Die verpleegdiensbestuur as leier word dan deur die gemeenskapsleiers erken en gesamentlike besluitneming omtrent sake rakende gesondheidsdienste word dan moontlik gemaak.

Die deelnemers was ook van mening dat die huidige burokratiese klimaat waarin die verpleegdiensbestuurder praktiseer nie bevorderlik is vir deelnemende leierskap of bestuur nie -derhalwe moet $n$ doelgerigte poging aangewend word om deelnemende leierskap en besluitneming toe te pas. Vervanging van die woorde "ek" met "ons" in die alledaagse interaksie met volgelinge word as belangrik beskou. Deelnemende leierskap of bestuur vereis bykomende inspanning en tyd, maar "... you can only be a leader by the cooperative efforts; if you are alone you can't do anything." Hier word ook die persoonlike eienskappe van die leier belangrik, soos toewyding, deursettingsvermoë en volgehoue kennisontwikkeling. Aanpasbaarheid deur die verpleegleier in hierdie tyd van dinamiese veranderinge is noodsaaklik.

Leierskap word deur die literatuur as in gesamentlike proses tussen die leier en volgelinge beskryf - derhalwe is dit nie moontlik om effektiewe leierskap in isolasie te beoefen nie (Blake \& Mouton, 1985:101-103; Coetzee, 1990:10; Hersey \& Blanchard, 1987:153; Muller, 1992:6; Rush, 1989:46/78). Die beginsels van deelnemende bestuur of besluitneming behoort dus as ' $n$ integrale dimensie van leierskapsbeoefening plaas te vind.

\section{c) Interpersoonlike vaardighede in leierskapsbeoefening}

Interpersoonlike vaardighede is as dimensie van voortreflike leierskapsbeoefening deur die verpleegdiensbestuurder uitgelig. Hier is die subkategoriee soos volg gesintetiseer selfkennis deur die leier, positiewe selfbeeld, mensekennis, selfhandhawende gedrag. kommunikasie en erkenning.

Die leier behoort oor selfkennis te beskik liggaamlik, psigies en geestelik. Hier speel nie net kennis en vermoëns ' $n$ belangrike rol nie, maar ook verwagtinge: "Leierskap beteken ook dat jy moet kyk watter verwagtings stel jy vir jouself ..." wat impliseer dat selfontwikkeling gebaseer is op selfkennis.
Vervolgens is " $n$ sterk selfbeeld ' $n$ voorvereiste vir leierskapsbeoefening: "'n Leier wat nie oor 'n sterk selfbeeld beskik nie, kan maklik bedreig voel en kan dan swik onder die druk van die eise wat aan haar gestel word." 'n Sterk selfbeeld in hierdie sin fokus die aandag ook op voortgesette persoonlike en professionele ontwikkeling deur die verpleegdiensbestuurder, want 'n vaste kennisbasis gee selfvertroue. Dit lei ook tot gemaklike verhoudings, nie net met die volgelinge nie maar ook met gemeenskaps/gesondheidsleiers. "One of the success stories of nurses who are effective leaders is that they are comfortable amongst others that they have to participate with, because they are well educated, they are knowledgable and they are able to verbalise what they have to say with confidence." Die selfbeeldisosialisering in die verpleegberoep is nie na wense nie - "... matrones wat in die gang af skreeu en raas" en vereis doelgerigte hersosialisering deur middel van voortgesette opleiding en ontwikkeling.

Mensekennis, veral omtrent die volgelinge, is ' $n$ belangrike interpersoonlike vaardigheid, veral in die multi-kulturele opset waarin die verpleegdiensbestuurder leierskap beoefen Mensekennis - liggaamlik, psigies en geestelik - is ' $n$ voorvereiste vir die delegering van gesag aan die volgelinge: "You got to recognize the strength in others and give them the opportunity to develop." Hiermee saam gaan onvoorwaardelike aanvaarding, vertroue en ondersteuning aan die volgelinge, asook toeganklikheid sodat die nodige ondersteuningsnetwerke in die verpleegdiens en gemeenskap ontplooi kan word.

Selfhandhawende gedrag deur die verpleegdiensbestuurder, binne en buite die gesondheidsdiens, is van kardinale belang, veral as leierskap beoefen word. Die leier moet haar/sy saak, standpunte en waardes met cortuiging kan stel. Weer eens moet die negatiewe sosialiseringsklimaat reggestel word waar die verpleegkundige ' $n$ ondergeskikte rol in die gesondheidsdienste gespeel het. Selfhandhawende gedrag vereis ook versiendheid: "Verpleegkundiges leer nie om oorsigtelik dinge in perspektief te sien nie, omdat hulle nie oor die muurtjies van hulle eie praktykareas kan kom nie." Terselfdertyd is alle kommunikasievaardighede belangrik veral binne professionele leierskapsverband: “... daar loop deur jou kommunikasiedraagdjies altyd so 'n goue draad deur, want dis hoe jy die mense kry om entoesiasties te woes en saam met jou te gaan waar jy hulle graag wil hê." Dit vereis toepaslike rolvertolking: "Ek onderstreep die rol van die verpleegdiensbestuurder as rolvertolker. As kommunikeerder wat kommunikasie reg moet cordra en wat " $n$ ontsaglike belangrike rol speel tussen verskillende rolvertolkers."

Sonder positiewe interpersoonlike vaardighede is leierskapsbeoefening net nie moontlik nie. Dit word deur die literatuur as oen van die mees belangrike dimensies van leierskap beskryf (Covey, 1992:237; Mulder, 1990:82-83; Rothman, 1991:12/17; Rush, 1989:69) 


\section{d) Die verpleegleier se waardes}

Die verpleegdiensbestuurder se verantwoordelikheidsin en handhawing van die beginsels word as belangrik vir leierskapsbeoefening gesien. Pligpleging word deur die deelnemers gebruik om die belang van verantwoordelikheidsin te beskryf. Die waardes, norme en standaarde behoort nougeset uitgeleef te word. "Dit is vir my ontsettend belangrik om ' $n$ missie te hê, maar ' $n$ mens moet ook 'n visie hê. Jy moet baie entoesiasties wees oor dinge waaroor jy regtig baie diep voel, want alleenlik as jy ernstig is en 'n passie het oor jou visie, kan jy ander mense entoesiasties maak." Die verpleegleier se onderliggende waardes is die dryfkrag vir sukses as leier of bestuurder. 'n Persoonlike filosofie of beskouing beïnvloed die verpleegdiens se missie en filosofie, wat binne die raamwerk van die gesondheidsdiens se beleidsverwagtinge uitgeleef word. Die deelnemers beklemtoon veral 'n oordrewe diensmotief wat deur die Suid-Afrikaanse verpleegleiers gedemonstreer word - dat die werk eerste kom. Hierdie diensmotief is 'n oordrewe roepingsbewustheid wat in die leier se funksionering gereflekteer word.

Die leier se waardestelsel speel, volgens die leierdeskundiges, ' $n$ belangrike rol. ' $n$ Persoon se waardestelsel rig die leier se besluitneming en is gebaseer op die leier se wêreldbeskouing, wat sy denke en handelinge rig. Die belangrikheid van ' $n$ uitgeklaarde persoonlike lewensbeskouing en filosofie, asook die leier se missie, word deur Meyer (1984:41) en Mulder (1990:98) bevestig. Meeste van die verpleegliteratuur beklemtoon ook die belang van ' $n$ waardestelsel in leierskapsbeoefening (Marriner-Tomey, 1992:44 en Robbins, 1984:507).

\section{e) Veranderingsbestuur in} leierskapsbeoefening

Die verpleegbestuurders en leiers behoort 'n buigsame en aanpasbare ingesteldheid te hê. As gevolg van die snelle veranderinge in die politieke en maatskaplike klimaat, sal herposisionering van verpleegdienste plaasvind sonder om bedreigd daaroor te voel. Selfs die tradisionele rolle van die verpleegdiensbestuurder en verpleegpraktisyn binne die gesondheidsdienste sal veranderinge ondergaan. "So ek dink aanpasbaarheid en om te voel dat jy kan saambeweeg en veranderinge hanteer, gaan beslis ' $n$ belangrike karaktertrek van ' $n$ verpleegleier wees." Dit vereis derhalwe dat die verpleegdiensbestuurders by uitstek oor veranderingsbestuursvaardighede behoort te beskik, as deel van leierskapsontwikkeling.

Aird (1991:45), du Preez (1992:1-10) en Slabbert (1991) bevestig almal die belangrikheid van verandering as ' $n$ komponent van suksesvolle bestuur of leierskap in die dinamiese omgewing waarin ons bevind. Strategiese bestuur en besluitneming word deur verskeie outeurs as 'n suksesfaktor in leierskapsbeoefening beskryf, ten einde herposisionering of verandering teweeg te bring (Casse, 1991:18 Kazemek, 1987:106; Kleiman, 1989:106-107; Robbertson, 1986:24). Die literatuur beklemtoon hoofsaaklik die leier se rigtinggewende verantwoordelikheid. Veranderingsbestuur word in hierdie studie as ' $n$ vaardigheid vir voortreflike leierskapsbeoefening beskryf.

\section{f) Selfbestuur in verpleegleierskap}

Hierdie aspek van leierskap is in 'n ernstige lig deur die deelnemers beskou. Hier is balans en ewewig tussen werk en sosiale verantwoordelikhede beklemtoon. "Die leier moet goed wees vir haarself. "I don't think we as leaders are kind to ourselves -1 think we are rotten to ourselves." Die beeld wat leiers voorhou kan 'n probleem vir werwing wees. "Die verpleegleiers is so verkoop aan hulle werk dat ek nie kans sien daarvoor nie, want hulle leef nie meer nie, hulle is net altyd besig met pligpleging." Die verpleegdiensbestuurder wat leierskap beoefen behoort dus ander belangstellings ook te hê en sy moet weet hoe om stres te hanteer. Selfbestuur liggaamlik, psigies en geestelik -is dus ' $n$ belangrike dimensie van voortreflike leierskapsbeoefening. "Die interne en eksterne faktore oefen ' $n$ invloed uit op jou as verpleegleier en dit is essensieel om dit te ontleed en dan daarvolgens jou doelwitte te bepaal." Die leier moet kan ontspan sonder om skuldig te voel.

Hierdie beskouings word deur die literatuur bevestig. Die leier behoort vernuwing van haar/homself as ' $n$ prioriteit te stel (Muller, 1992).

\section{Leierskapsontwikkeling van verpleegdiensbestuurders}

Leierskapsontwikkeling van die verpleegdiensbestuurder is belangrik. Die volgende ontwikkelingstrategiee is deur die deelnemers beklemtoon, naamlik voortgesette onderwys, integrering tussen die akademie en dienste, loopbaanbeplanning en die benutting van die beskikbare onderwystegnologie. Vaardigheidsontwikkeling behoort veral klem te lê op die volgende aspekte:

- bestuurstyle van verpleegleiers;

- interpersoonlike vaardighede;

- leierskapstyle, met die klem op gebeurlikheidstyl;

- kreatiewiteit en selfwerksaamheid;

- streshantering;

- konflikhantering en arbeidsverhoudinge;

- tydbestuur;

- spanbou en groepsdinamika

- persoonlike ontwikkeling van die verpleegleier;
- integriteit en geloofwaardigheidsbeginsels.

Meeste van die deelnemers is van mening dat die verpleegdiensbestuurder wat as leier optree, 'n gegradueerde persoon behoort te wees. Leiersvorming vind egter reeds in die basiese opleiding plaas en potensiële leiers moet reeds vroeg ontwikkel word. Dit word egter beklemtoon dat leierskapsontwikkeling 'n lewenslange volgehoue proses is. Leiersvorming moet ook op die veranderinge ingestel wees: "The real leaders, if you look at them, they were the ones that had the ability to learn from the situation and from the world around them. To me it is of course a lifelong position." Die eksterne omgewingsveranderlikes is dus bepalend vir volgehoue leiersvorming. Dit vereis goed-beplande personeelontwikkelings-programme in die gesondheidsdienste om die leiers op operasionele vlak op hoogte van die nodige veranderinge te bring en sodoende paraatheid te fasiliteer. Nouer skakeling tussen universiteite en dienste is ook bepleit: "Daar moet meer skouerskuur tussen die dienste en die akademie wees."

Die stelsel van personeelbevordering in die staatsdiens blyk ' $n$ negatiewe invloed op leierskapsontwikkeling te hê en daar word meer buigsaamheid aanbeveel sodat jong leiers die geleentheid kan hê om bevordering te kry. Die ouderdom is ook as veranderlike aangespreek: "Die leier moet ook nie bedreig voel deur die mense wat jonger is en wat beter gekwalifiseerd is as hyself nie. Hy het kwaliteite wat hulle ook weer nie het nie en so vul hulle mekaar aan."

Die deelnemers was verder van mening dat die onderwystegnologie beter aangewend kan word om leierskapsontwikkeling te bevorder. Die daarstelling en benutting van takseersentra is aanbeveel, asook meer kreatiewe simulasie-strategieè. Die takseersentra impliseer ' $n$ instelling waar die verpleegkundige se leierskapsvermoëns deur kundiges beoordeel kan word.

Die burokratiese of outokratiese klimaat waarin leierskap beoefen word, benodig regstelling en doelgerigte hersosialisering van verpleegdiensbestuurders in hierdie verband.

Konseptuele definisie van voortreflike leierskapsbeoefening en toepassing van leierskapsdimensies deur die verpleegdiensbestuurder

Leierskapsvoortreflikheid deur die verpleegdiensbestuurder word gedemonstreer deur rolmodellering, waardesekerheid, deelnemende leierskap, veranderings- en selfbestuur, asook positiewe interpersoonlike vaardighede.

Die verpleegdiensbestuurder as rolmodel is ' $n$ geestelike wese wat op in geintegreerde biopsigososiale wyse strewe na persoonlike en professionele heelheid by haar/homself en volgelinge, en demonstreer liggaamlike. 
psigiese en geestelike vermoëns (leiers/ bestuursvaardighede) vir leierskapsbeoefening.

Deelnemende leierskap as ' $n$ leierskapsdimensie bied wedersydse geleenthede aan die verpleegdiensbestuurder en volgelinge om die proses van groepsdinamika te verbeter deurdat die verpleegdiensbestuurder en volgelinge se gemeenskaplike doelwitte gestel en bereik word en wedersydse vertroue gekommunikeer word wat weerstand teen besluitneming en verandering verminder in die strewe na leierskapsvoortreflikheid in die verpleegdiens.

Die verpleegdiensbestuurder is ' $n$ geestelike wese wat op 'n geïntegreerde biopsigososiale wyse in voortdurende interaksie met een meer persone in die verpleegdiens is waar hy/sy sodanige interpersoonlike vaardighede van aanvaarding, vertroue, ondersteuning, doeltreffende kommunikasie en konstruktiewe konflikhanteringsmeganismes anwend, om deur middel van selfkennis en ' $n$ positiewe selfbeeld, bekwame doelgerigte interpersoonlike vaardighede te fasiliteer sodat in die behoeftes van die verpleegdiens en volgelinge voorsien sal word in haar/sy strewe na voortreflike leierskapsbeoefening in die verpleegdiens.

Die verpleegdiensbestuurder se waardesekerheid voorsien in basiese cortuigings van wat reg of verkeerd is en reflekteer haar/sy persoonlike en professionele strewe ha heelheid -liggaamlik, psigies en geestelik - deur die fasilitering van ' $n$ persoonlike en professionele filosofie, missie en visie in die verpleegdiens in haar/sy strewe na leierskapsvoortreflikheid, binne die konteks van dienslewering.

Veranderingsbestuur dui op die verpleegdiensbestuurder se vermoë om deur middel van die wetenskaplike metode van beraming (van interne en eksterne omgewingsveranderlikes), beplanning, implementering en evaluering van toepaslike hanteringsmeganismes en veranderingstrategieè, in die strewe na heelheid en leierskapsvoortreflikheid in die verpleegdiens.

Selfbestuur is ' $n$ dinamiese interaksieproses tussen die verpleegdiensbestuurder se interne omgewing (liggaamlik, psigies en geestelik) en die eksterne omgewingseise (fisiek, sosiaal en geestelik) om ' $n$ balans te handhaaf in die strewe na heelheid en leierskapsvoortreflikheid in die verpleegdiens.

\section{GEVOLGTREKKINGS EN AANBEVELINGS}

Die beskouinge van die Suid-Afrikaanse verpleegleier oor die kenmerke van voortreflike leierskapsbeoefening deur die verpleegdiensbestuurder, stem grootliks coreen met dit wat die literatuur of bestaande navorsing reeds as kennis gegenereer het. Die verpleegleier se oordrewe roepings bewustheid en verhoogde sin vir pligpleging of dienslewering, word egter nie in tradisionele literatuur oor leierskap so eksplisiet gestel nie. 'n Besliste klemverskuiwing na deelnemende leierskapsbeoefening word in hierdie resultate uitgelig. Dit blyk dat deelnemende bestuur en deelnemende leierskapsbeoefening op in geïntegreerde wyse behoort plaas te vind en die prosedure van deelnemende besluitneming oordraagbaar is in ' $n$ model oor leierskapsbeoefening en leierskapsontwikkeling.

Alhoewel rigtinggewing nog altyd deel van leierskapsbeoefening in die literatuur beskryf is, kry veranderingsbestuur as leierskapsvaardigheid meer $\mathrm{klem}$ in hierdie studie. Leiersvorming of leierskap- sontwikkeling van verpleegdiensbestuurders vind ook nie na wense plaas nie.

Die volgende sentrale kenmerke of dimensies van voortreflike leierskapsbeoefening deur die verpleegdiensbestuurder is geidentifiseer binne konteks van verpleegdiensbestuur beskryf:

- die verpleegdiensbestuurder as rolmodel;

- waardesekerheid deur die verpleegdiensbestuurder;

- deelnemende leierskap;

- veranderingsbestuur;

- selfbestuur;

- interpersoonlike vaardighede.

Daar word aanbeveel dat hierdie dimensies as konsepte benut word in die beskrywing van ' $n$ model vir leierskapsontwikkeling van verpleegdiensbestuurders in Suid-Afrika. Die beplanning, implementering en evaluering van 'n leierskapsontwikkelingsprogram vir verpleegdiensbestuurders word vervolgens aanbeveel, gebaseer op die geidentifiseerde behoeftes, met inagneming van die bestaande onderwystegnologie. Die ontwikkeling van ' $n$ takseersentrum vir verpleegleiers word ook aanbeveel.

\section{Erkenning}

Hierdie artikel is gebaseer op die eerste fase van ' $n$ doktorale studie. Hiermee word die verpleegleiers/bestuurders wat aan die studie deelgencem het bedank vir hul waardevolle bydrae en "pligpleging" na 'n vol dag se werk. Die Suid-Afrikaanse Verpleegstersvereniging word bedank vir finansiële steun.

\section{VERWYSINGS}

AIRD, B (1990): Agents for change. Nursing Times, 86(10), March 1990: 7, 43 - 46

BLAKE, RR \& MOUTON, JS (1985): The managerial grid 111 . Houston: Gulf.
CALLAHAN, CB \& WALL, LL (1987): Participative management: a contingency approach. Journal of Nursing Administration, 17(9), September 1987. 9-14.

CASSE, P (1991): Deciding on change: what and how? European Management Journal, 9(1), March 1991:18-21.

COVEY, SR (1992): The seven habits of highly effective people. London: Simon \& Schuster.

COETZEE, LD (1990): Onderpresterende bestuurders in senior bestuursposisies. PU vir $\mathrm{CHO}$ ongepubliseerde.

DU PREEZ, S (1992): Toespraak oor veranderinge. Suid-Afrikaanse Verpleegstersvereniging (ongepubliseerd)

DUNHAM, J \& KLAFEHN, KA (1990): Transformational leadership and the nurse executive. Journal of Nursing Administration, 20(4): 28-33.

FIELD, PA \& MORSE, JM (1985): Nursing research: the application of qualitative approaches. Maryland: Aspen.

HERSEY, P \& BLANCHARD, KH (1987): Management of organizational behaviour: utilizing human resources. Englewood Cliffs: Prentice Hall.

KAZEMEK, EA (1989): Coping with change in the health care industry. Health Care Financial Management, 43(1), 106.

KERLINGER, FN (1986): Foundations of behavioural research. New York: Holt, Rinehar and Winston.

KINGRY, MJ; TIEDJE, LB \& FRIEDMAN, LL (1990): Focus groups: a research technique for nursing. Nursing Research,39(2),124-125.

KLEIMAN, M (1989): Ease the stress of change. Personal Journal, September 1989:106-109.

KOTZè, WJ (1991): Professionele weerbaarheid: opleiding vir verpleegleierskap. Port Elizabeth Universiteit (ongepubliseerde toespraak).

MACOBY, M (1990): How to be a quality leader. Research Technology Management, 33(5), September/October 1990:51-52

MARRINER-TOMEY, A (1992): A guide to nursing management; fourth edition. St Louis: Mosby.

MEYER, PJ (1984): The dynamics of personal leadership. Plan of action; fourth edition. Texas: Success motivation interaction. 
MOUTON, J \& MARAIS, HC (1990): Basiese begrippe. Metodologie van die geesteswetenskappe. Pretoria: RGN.

MULDER, CT (1990): Faculty dialogue. Journal of the Institute for Christian Leadership, 13 Winter 1990:79-103.

MULLER, ME (1992): Grondslae van leidinggewing. Johannesburg: RAU (ongepubliseerde lesings).

ORAL ROBERTS UNIVERSITY (1990): Self-study report, submitted to the council of Baccalaureate and higher degree programs, National League for Nursing. August 1990: Volume 1 -Narritive by Criteria. Tulsa, Oklahoma: Oral Roberts University Anna Vaughn School of Nursing.
PARSE, FP; COYNE, AB \& SMITH, MJ (1985): Nursing research -qualitative methods. Maryland: Brady communications.

POLIT, DF \& HUNGLER, BP (1987): Nursing research. Principles and methods; third edition. London: Lippincott.

ROBBINS, SP (1984): Management: concepts and practices. Englewood Cliffs: Prentice Hall.

ROBERTSON, B (1986): Creative nursing management. Nursing RSA Verpleging, 1(2), March 1986:23-25.

ROTHMAN, S (1991): Interpersoonlike vaardigheidsopleiding. Potchefstroom: Regurk Drukkery.
RUSH, M (1989): Management: a Biblical approach. USA: Victor Books.

SLABBERT, CF (1991): Embargo: vergadering van die sentrale besturur van die Suid-Afrikaanse Verpleegstersvereeniging. Junie 1991

WOODS, NF \& CATANZARO,M (1988): Nursing research. Theory and practice. St Louis: Mosby.

Albe Nel: D.Cur.-student RAU Verpleegkunde

Marie Muller: Professor RAU Verpleegkunde

Marie Poggenpoel: Professor RAU Verpleegkunde 